\title{
Evaluation of Antihyperlipidaemic and Antioxidant Activity of Astercantha longifolia (Linn.) Nees and Pergularia daemia (Forsskal) Chiov
}

\section{T. P. Kumari Pushpa Rani}

Department of Microbiology, St.Mary's College (Autonomous), Tuticorin

\author{
A. Doss* \\ PG and Research Department of Botany, V.O.Chidambaram College, Tuticorin \\ Email: androdoss@gmail.com
}

\section{S. P. Anand}

PG and Research Department of Botany, National College (Autonomous), Tiruchirapalli

\author{
Article History \\ Received: November 14, 2020 \\ Revised: December 25, 2020 \\ Accepted: December 28, 2020 \\ Published: December 30, 2020
}

\begin{abstract}
Objective: To evaluate the antioxidant and antihyperlipidaemic effect of methanol extracts of Asteracantha longifolia and Pergularia daemia leaf in alloxan induced diabetic rats. Methods: Swiss albino rats were made diabetic by a single dose of alloxan monohydrate ( $150 \mathrm{mg} / \mathrm{kg}$ i.p.). Blood glucose levels and body weights of rats were measured using on weekly intervals i.e day $0,7,14$ and 21 after daily administration of both extracts at dose $200 \mathrm{mg} / \mathrm{kg}$ bw. Other biochemical parameters such as serum cholesterol, triglycerides, low density lipoprotein-cholesterol, very low density lipoproteincholesterol, high density lipoprotein-cholesterol, phospholipids and serum protein, albumin, globulin levels were also measured at the end of study. The antioxidant enzymes (CAT, SOD \& GSH) were also measured in the diabetic rats. Results: In the acute toxicity study, methanol extract of both plants were non-toxic at $2000 \mathrm{mg} / \mathrm{kg}$ in rats. The increased body weight, decreased blood glucose and other biochemical parameters level were observed in diabetic rats treated with methanol extracts of both plants compared to diabetic control rats. The antioxidant activity of both plant extracts were also exhibited significant activity. In diabetic rats, methanol extract of both plants administration, altered lipid profiles were reversed to near normal than diabetic control rats. Conclusions: Methanol extract of both plants (Asteracantha longifolia and Pergularia daemia) leaf possesses significant antioxidant and antihyperlipidaemic activity in diabetic rats.

Keywords: Alloxan monohydrate; VLDL; LDL; HDL; SOD; CAT.
\end{abstract}

\section{Introduction}

Diabetes mellitus is one of the most commonly encountered diseases across the world. WHO recently compiled the data to show that the total number of people diagnosed with Diabetes is around 150 million. It is assumed that this number will be double by the year 2025 and most the affected patients' age will be 65 years or more [1]. At present in India the number of people with diabetes is around 40.9 million and it is expected to rise to 69.9 million by 2025 . India has emerged as the diabetic capital of the world [2]. The Indian Diabetes Federation International Diabetes Federation [3] (IDF) estimated 3.9 million deaths for the year 2010, which represented $6.8 \%$ of the total global mortality. Currently available therapies for diabetes include insulin and various oral antidiabetic agents such as sulfonylureas, biguanides and glinides. Many of them have a number of serious adverse effects; therefore, the search for more effective and safer hypoglycemic agents is one of the important areas of investigation. In recent days, herbal medicines are used worldwide even without documentation of their curative effect and there is only little essential to know about the pharamacological evaluation of various plants used in the traditional system of medicines [4]. A number of investigations confirmed that oral anti-hyperglycemic agents derived from plants can be used in traditional medicine and many of the plants were found with good antidiabetic activity $[5,6]$. So, the present study was conducted to evaluate antihyperlipidaemic and antioxidant and antihyperlipidaemic activities of Asteracantha longifolia and Pergularia daemia leaves in alloxan induced diabetic rats.

Asteracantha longifolia, a perennial angiosperm of Acanthaceae, widely distributed semi-aquatic herb in India, is being used as vegetable in some states like Odisha, Chhattisgarh and West Bengal. The whole plant, roots, seeds, and ashes of the plant are extensively used in traditional system of medicine for various ailments like rheumatism, inflammation, jaundice, hepatic obstruction, pain, urinary infections, oedema and gout [7]. This plant contains various groups of phyto-constituents viz. phytosterols, fatty acids, minerals, polyphenols, proanthocyanins, mucilage, alkaloids, enzymes, amino acids, carbohydrates, hydrocarbons, flavonoids, terpenoids, vitamins, glycosides, etc.

The plant Pergularia daemia (Family: Asclepiadaceae) is known as "Uttaravaruni" in Sanskrit and "Utranajutuka" in Hindi. In ethanomedicinal practices the traditional healer use Pergularia daemia (Asclepiadaceae) as anthelmentic, emetic, thermogenic, expectorant, antipyretic and laxative. Leaves juice is given in catarrahal 
affections, asthma, and infantile diarrhoea and is applied to inflammatory swelling in combination lime [8]. Plant has been documented for presence of presence of triterpenes, saponins cardenolides and alkaloids [9], while Anjaneyulu, et al. [10] reported the presence of triterpenes and steroidal compound.

\section{Materials and Methods}

\subsection{Collection of Plant Materials}

Fresh plant parts of selected plant samples (A.longifolia and P. daemia) were collected randomly from the gardens and villages of Trichy district, Tamilnadu from the natural stands. The botanical identity of this plant was confirmed by Botanical Survey of India (Southern Circle), Coimbatore, Tamilnadu. A voucher specimen has been deposited at the Department of Botany, National College (Autonomous), Tiruchirapalli-620 001, Tamilnadu, India.

\subsection{Preparation of Extract}

One hundred grams (100 g) of dried plant powdered samples were extracted with $200 \mathrm{ml}$ of methanol kept on a rotary shaker for $24 \mathrm{~h}$. Thereafter, it was filtered and centrifuged at $5000 \mathrm{~g}$ for $15 \mathrm{~min}$. The supernatant was collected and the solvent was evaporated to make the final volume one-fifth of the original volume. It was stored at $4^{\circ} \mathrm{C}$ in airtight bottles for further studies.

\subsection{Animals}

The animals of both sexes were used for these experiments. They were obtained from Animal House, RVS Pharmaceutical Sciences, Coimbatore, Tamilnadu. The animals were housed in standard cages and were maintained on a standard pelleted feed and water was given ad libitum. All the experiments were carried out according to the guidelines recommended by the Committee for the Purpose of Control and Supervision of Experiments of Animals (CPCSEA), Government of India.

\subsection{Induction of Diabetes}

The animals were fasted for $24 \mathrm{~h}$ and diabetes was induced by a single intraperitoneal injection of a freshly prepared solution of alloxan monohydrate $(150 \mathrm{mg} / \mathrm{kg}$ b.w. $)$ in sterile normal saline. $72 \mathrm{~h}$ later, rats with blood glucose (BGL) levels above $200 \mathrm{mg} / \mathrm{dl}$ were considered diabetic and selected for the experiment.

\subsection{Treatment Protocol}

Diabetic animals were randomly assigned into following groups of five animals each.

Group I: Normal control received distilled water.

Group II: Diabetic control received vehicle (Distilled water)

Group III: Diabetic rats received methanol extract of A. longifolia $(250 \mathrm{mg} / \mathrm{kg})$

Group IV: Diabetic rats received methanol extract of $P$. daemia $(250 \mathrm{mg} / \mathrm{kg})$

Group V: Diabetic rats received glibenclamide $(10 \mathrm{mg} / \mathrm{kg})$

The drug solutions or vehicle were administered orally by gastric intubation once daily at $11^{\circ}$, clock for 21 days. The effect of vehicle, extract and standard drug on blood glucose and body weight was determined in animals at $0,7,14,21$ days after oral drug administration.

\subsection{Estimation of Protein Albumin and Globulin}

Serum protein [11] and serum albumins and globulins [12] were determined by quantitative colorimetrically method. The total protein minus the albumin gives the globulin, serum glutamate pyruvate transaminase (SGPT) and serum glutamate oxaloacetate transaminase (SGOT) was measured spectrophotometrically by utilizing the method of Reitman and Frankel [13].

\subsection{Estimation of Lipids and Lipoprotein}

Serum cholesterol (TC) [14], triglycerides (TG) [15], low density lipoprotein cholesterol (LDL-C) [16], very low density lipoprotein cholesterol (VLDL- C), high density lipoprotein cholesterol (HDL-C) [17] and phospholipids were analyzed.

\subsection{Determination of Antioxidant Parameters}

Antioxidant parameters such as Catalase [18], Superoxide dismutase [19][19] and GSH [20] were determined.

\section{Results}

The overall study showed the $\mathrm{LD}_{50}$ of oral toxicity of all extracts to be above $2000 \mathrm{mg} / \mathrm{kg}$ b.w. in rats. So, the extracts are safe for long term administration. The effects of vehicle, methanol and Glibenclamide extracts on blood glucose levels in normal and diabetic rats after treatment of 21 days are shown in Table 1, in which all extracts showed significant reduction $(\mathrm{P}<0.01)$. It was observed that standard drug glibenclamide lowered the blood glucose levels significantly bringing it back to normal which is an indication of the presence of some beta cells, as glibenclamide is known to stimulate insulin secretion from beta cells. 
Sumerianz Journal of Biotechnology

Table-1. Effect of A.longifolia and P.daemia extracts on the serum glucose levels of normal, diabetic induced and drug treated rats

\begin{tabular}{l|l|l|l|l}
\hline Treatment groups & 0day $(\mathbf{m g} / \mathbf{d l})$ & $\mathbf{7}^{\text {th }} \mathbf{d a y}(\mathbf{m g} / \mathbf{d l})$ & $\mathbf{1 4}^{\text {th }} \mathbf{d a y}(\mathbf{m g} / \mathbf{d l})$ & $\mathbf{2 1}^{\text {st }} \mathbf{d a y}(\mathbf{m g} / \mathbf{d l})$ \\
\hline Group I & $94.16 \pm 2.35$ & $99.46 \pm 2.40$ & $90.16 \pm 1.40$ & $95.26 \pm 2.55$ \\
\hline Group II & $241.33 \pm 3.98$ & $262.23 \pm 1.51$ & $294.16 \pm 2.30^{*}$ & $310.13 \pm 4.50^{*}$ \\
\hline Group III & $248.30 \pm 1.45$ & $190.63 \pm 3.32$ & $143.10 \pm 1.36^{*}$ & $115.26 \pm 6.30^{*}$ \\
\hline Group IV & $246.66 \pm 1.49$ & $192.23 \pm 2.40$ & $154.50 \pm 4.40^{*}$ & $118.08 \pm 1.25^{*}$ \\
\hline Group V & $278.23 \pm 3.32$ & $183.50 \pm 6.20$ & $141.40 \pm 3.55^{*}$ & $111.16 \pm 1.15^{*}$ \\
\hline
\end{tabular}

Value represent mean \pm S.D. $(\mathrm{n}=5)$; Statistical significance is as follows $* p<0.05 ; * * p<0.01 ; * * * p<0.001$

\subsection{Lipid Profiles}

Table 2 shows the levels of TC, TG, LDL-C, HDL-C, VLDL-C and Phospholipid in the serum of diabetic rats showed significantly increased serum lipid profiles except HDL-C when compared with normal rats. The methanol extracts of both plants treated rats showed a significant decrease in the content of lipid profiles when compared with diabetic rats. Similarly HDL-C level decreased in alloxan induced diabetic rats when compared with normal rats. Administration of methanol extract of both plants and glibenclamide to the diabetic rats. HDL-C level was found to be restored to normal.

Table-2. Effect of A.longifolia and P.daemia extracts on the serum lipid profile of normal, diabetic induced and drug treated rats

\begin{tabular}{|c|c|c|c|c|c|c|}
\hline $\begin{array}{l}\text { Treatment } \\
\text { groups }\end{array}$ & ${ }^{1} \mathbf{T C}$ & ${ }^{2} \mathrm{TG}$ & ${ }^{1}$ HDL-C & ${ }^{1}$ LDL-C & ${ }^{1}$ VLDL-C & ${ }^{1}$ Phospholipid \\
\hline Group I & $72.22 \pm 3.90$ & $62.07 \pm 1.16$ & $32.10 \pm 0.43$ & $26.31 \pm 0.31$ & $12.11 \pm 0.20$ & $130.23 \pm 1.90$ \\
\hline Group II & $120.07 \pm 1.06^{* *}$ & $91.20 \pm 3.54^{*}$ & $28.84 \pm 0.67 * *$ & $50.99 \pm 1.26^{* *}$ & $18.58 \pm 0.42$ & $170.22 \pm 2.90 * *$ \\
\hline Group III & $76.22 \pm 6.80^{\mathrm{a}}$ & $65.25 \pm 8.78^{\mathrm{a}}$ & $35.48 \pm 1.93^{\mathrm{a}}$ & $26.89 \pm 0.33^{\mathrm{a}}$ & $12.43 \pm 0.54^{\mathrm{a}}$ & $132.63 \pm 1.81^{\mathrm{a}}$ \\
\hline Group IV & $79.35 \pm 2.76$ & $69.56 \pm 2.74$ & $34.06 \pm 1.76$ & $31.25 \pm 0.35$ & $13.17 \pm 2.21$ & $136.75 \pm 1.52$ \\
\hline Group V & $74.70 \pm 1.27$ & $68.25 \pm 1.66$ & $34.72 \pm 1.83$ & $26.33 \pm 1.18$ & $13.65 \pm 0.23$ & $130.91 \pm 0.77$ \\
\hline
\end{tabular}

\subsection{Biochemical Parameters}

The level of total protein, albumin and liver marker enzymes such as SGPT and SGOT in the serum of diabetic rats are presented in table 3. Significant reductions in serum protein, albumin, globulin were observed in alloxan induced diabetic rats (Group II) when compared to control rats (Group I). On administration of methanol extracts of both plants to the diabetic rats, protein, albumin, globulin levels were found to be restored in normal. Also the SGPT and SGOT levels were elevated significantly in alloxan induced diabetic rats compared to control rats.

Table-3. Effect of A.longifolia and P.daemia extracts on the serum protein, albumin, globulin, SGPT and SGOT level of normal, diabetic induced and drug treated rats

\begin{tabular}{l|l|l|l|l|l}
\hline Treatment groups & ${ }^{1}$ Protein & ${ }^{1}$ Albumin & ${ }^{1}$ Globulin & SGPT & SGOT \\
\hline Group I & $7.25 \pm 0.12$ & $4.06 \pm 0.08$ & $3.19 \pm 0.40$ & $11.33 \pm 2.86$ & $15.74 \pm 2.47$ \\
\hline Group II & $6.59 \pm 0.83^{*}$ & $3.71 \pm 0.12 *$ & $2.88 \pm 0.61$ & $25.67 \pm 3.065$ & $32.48 \pm 2.51$ \\
\hline Group III & $7.49 \pm 0.36$ & $3.98 \pm 0.15$ & $3.51 \pm 0.55$ & $13.62 \pm 2.08$ & $15.78 \pm 3.10$ \\
\hline Group IV & $7.50 \pm 0.10$ & $3.97 \pm 0.76$ & $3.53 \pm 0.21$ & $13.59 \pm 1.17$ & $18.42 \pm 2.01$ \\
\hline Group V & $8.26 \pm 0.85$ & $4.42 \pm 0.55$ & $3.84 \pm 0.65$ & $12.46 \pm 1.66$ & $14.79 \pm 1.51$ \\
\hline
\end{tabular}

Value represent mean \pm S.D. $(\mathrm{n}=5)$; Statistical significance is as follows $* p<0.05 ; * * p<0.01 ; * * * p<0.001$ ${ }^{1} \mathrm{~g} / \mathrm{dl} ;{ }^{2} \mathrm{u} / \mathrm{l}$

\subsection{Antioxidant Parameters}

The data depicted in table 4 shows the effect of crude extracts of both plants on plasma reduced glutathione, catalase and superoxide dismutase levels were found to be significantly higher in alloxan induced diabetic rats compared to normal rats. The extracts at dose $250 \mathrm{mg} / \mathrm{kg}$ b.w significantly reduced the levels of antioxidant enzymes (SOD \& CAT) in diabetic rats. Plasma GSH level was found to be significantly lowered in alloxan diabetic rats as compared to normal rats. The chronic administration of crude extracts of both plants significantly increased the level of glutathione in diabetic rats.

Table-4. Effect of A.longifolia and P.daemia extracts on the serum antioxidant parameters of normal, diabetic induced and drug treated rats

\begin{tabular}{l|l|l|l}
\hline Treatment groups & GSH $(\boldsymbol{\mu m} / \mathbf{m g}$ protein $)$ & SOD $(\boldsymbol{\mu m} / \mathbf{m g}$ protein $)$ & CAT $(\boldsymbol{\mu m} / \mathbf{m g} \mathbf{~ p r o t e i n})$ \\
\hline Group I & $29.47 \pm 1.07$ & $411.74 \pm 3.11$ & $66.57 \pm 0.89$ \\
\hline Group II & $18.69 \pm 0.60^{*}$ & $296.09 \pm 6.0^{* *}$ & $28.55 \pm 0.51^{* *}$ \\
\hline Group III & $28.42 \pm 0.50$ & $402.61 \pm 6.81$ & $68.56 \pm 0.46$ \\
\hline Group IV & $28.68 \pm 0.51$ & $394.87 \pm 4.41$ & $67.69 \pm 0.73$ \\
\hline Group V & $30.52 \pm 0.71$ & $408.31 \pm 2.40$ & $70.01 \pm 0.78$ \\
\hline V
\end{tabular}

Value represent mean \pm S.D. $(\mathrm{n}=5)$; Statistical significance is as follows $* p<0.05 ; * * p<0.01 ; * * * p<0.001$

\section{Discussion}

The prevention of diabetes is an urgent worldwide health concern. The period preceding the onset of type 2 diabetes is typically characterized by obesity and insulin resistance induced by over reacting and physical inactivity. 
The methanol extract of Asteracantha longifolia and Pergularia daemia (Group III \& IV) was treated on alloxan induced diabetic rats (Group II). The results were compared with control (Group I) and the positive control glibenclamide (Group V) after twenty one days of treatment based on biochemical parameters. After the alloxan induction, glucose, lipid profiles, protein and antioxidant were restored to control levels with the administration of the known drug glibenclamide and plant extracts. The result from the present study shows the significant changes in biochemical parameter during the experimentally inducted diabetes. The administration of methanol extract of both plants decreases the blood glucose level whereas; serum insulin level was increased in treated rats compared to control rats. The hypoglycemic methanol extract of both plants was found to be inducing insulin release from pancreatic cells of diabetic rats.

Cholesterol is a powerful risk factor for many coronary heart diseases. The degree of hypercholesterolemia is directly proportional to severity in diabetes. In our study, we have observed higher levels of cholesterol in plasma of diabetic rats. Further, alloxan induced diabetic rats when treated with petroleum ether and chloroform extracts significantly reduced the serum cholesterol level. It has been reported that plant extracts exert their cholesterol lowering effect seems to be a decrease in cholesterol absorption from the intestine, by binding with bile acids within the intestine and increasing bile acids excretion [21]. A significant increase in serum cholesterol and triglycerides observed in alloxan induced diabetic rats in our experiment is in agreement with the findings of the aforementioned studies. The marked hyperlipidemia that characterizes the diabetic state may therefore be regarded as a consequence of the uninhibited actions of lipolytic hormones on the fat depots [22].

A significant reduction in serum protein, albumin and globulin were observed in alloxan induced diabetic rats, when compared to control and glibenclamide treated rats. On administration of methanol extract of both plants to the diabetic rats, protein, albumin and globulin levels were found to be restored in normal. The increased level of serum protein, albumin and globulin in alloxan induced diabetic rats are presumed to be due to increased protein catabolism and gluconeogenesis during diabetes [23]. The serum SGOT and SGPT levels increases as a result of metabolic changes in the liver, such as administration of toxin, cirrhosis of the liver, hepatitis and liver cancer including diabetes [24]. Similarly in the present study, it was observed that the levels of SGPT and SGOT in alloxan induced diabetic rats were elevated. It may be due to leaking out of enzymes from the tissues and migrating into the circulation by the adverse effect of alloxan [25]. SGOT and SGPT were used as markers to assess the extent of liver damage in streptozotocin induced diabetic rats [26].

Free radical reacts with lipids causing peroxidation, resulting in the release of products such as malondialdehyde, hydroperoxide and hydroxyl radicals. These extracts have the capacity to scavenge free radicals directly or interfering with generation of free radicals [27, 28]. Thus, the inhibitory effects of these extracts on oxidative damage may be attributed to the suppression induced Peroxidation [29]. It is well known that CAT, SOD and reduced glutathione play an important role as protective enzymes against free radical formation in tissues. Several investigators have reported that the reduced activities of CAT and SOD genes are induced by free radicals and also by certain humoral factors $[30,31]$. The present study indicates the reduction in the activity of SOD, CAT and GSH in alloxan induced rats. These results reveal the protective role of plant extract in decreasing lipid peroxidation and by normalizing antioxidant system.

In conclusion, the methanol extract of A.longifolia and P.daemia leaves exhibits potent antihyperglycemic, antioxidative and lipid lowering activity in alloxan diabetic rats. These results support its traditional use in the treatment of diabetes and cardiovascular disease. Finally, the precise mechanism(s) and site(s) of action and the active constituent(s) involved are still to be determined in addition to toxicological studies.

\section{References}

[1] Soumya, M. and Anima, P., 2014. "Potential anti-diabetic plants of eastern India- A review article." BMR Phytomedicine, vol. 1, pp. 1-11.

[2] Joshi, S. R. and Parikh, R. M., 2007. "India - diabetes capital of the world: now heading towards hypertension." Journal of the Association. Physicians India., vol. 55, pp. 323-324.

[3] International Diabetes Federation, 2009. IDF Diabetes Atlas. 4th ed. Belgium: IDF, Brussels. pp. 21-27.

[4] Gupta, R., Bajpai, K. G., Johri, S., and Saxena, A. M., 2008. "An overview of Indian novel traditional medicinal plants with antidiabetic potential." African Journal of Traditional Compliment and Alternative Medicine, vol. 8, pp. 1-17.

[5] Kesari, A. N., Gupta, R. K., Singh, S. K., Diwakar, S., and Watal, G., 2006. "Hypoglycemic and antihyperglycemic activity of Aegle marmelos seed extract in normal and diabetic rats." Journal of Ethnopharmacology, vol. 107, pp. 374-379.

[6] Kesari, A. N., Kesari, S., Singh, S. K., Gupta, R. K., and Watal, G., 2007. "Studies on the glycemic and lipidemic effect of Murraya koenigii in experimental animals." Journal of Ethnopharmacology, vol. 112, pp. 305-311.

[7] Lobo, V. C., Anita, P., and Naresh, C., 2010. "Antioxidant and free radical scavenging activity of Hygrophila schulli (buch.-ham.)." Almeida and Almeida. Seeds. Advances in Bioreseach., vol. 1, pp. $72-78$.

[8] Kirtikar, K. R. and Basu, B. D., 1999. Indian medicinal plants vol. 3. Dehardun: International Book Distributors.

[9] Sathish, C. J., Sharma, R. A., Jain, R., Mascolo, N., Capasso, F., Vijayvergia, R., and Mittal, C., 1998. "Ethnopharmacological evaluation of Pergularia daemia (Forsk) Chiov." Phytotherapy Research, vol. 12, pp. 378-80. 


\section{Sumerianz Journal of Biotechnology}

[10] Anjaneyulu, A. S. N., Raju, D. V. S. N., and Rao, S. S., 1998. "Chemical evaluation of Pergularia extensa." Indian Journal of Chemistry, vol. 37B, pp. 318-20.

[11] Lowry, O. H., Rosebrough, N. J., Farr, A. L., and Randall, R. J., 1951. "Protein measurement with the Folin phenol reagent." Biological Chemistry, vol. 193, pp. 265-275.

[12] Wolfson, W. Q., Cohn, C., Calvary, C., and Ichiba, F., 1948. "Studies in serum protein-Rapid procedure for the estimation of total proteins, true albumin, total globulin, alpha globulin, beta globulin and gamma globulin." American Journal of Clinical Pathology, vol. 18, pp. 723-730.

[13] Reitmans and Frankel, 1957. "A colorimetric method for the determination of SGOT and SGPT." Am. J. Cli. Pathol., vol. 28, pp. 56-63.

[14] Parekh, A. C. and Jung, 1970. "Cholesterol determination with ferric acetate, uranium acetate and sulphuric acid, ferrous sulphate reagent." Annals Chemistry, vol. 112, pp. 1423-1427.

[15] Rice, E. W., 1970. Triglycerides in serum in: Standard methods. Clinical chemistry. 9th ed. New York: Roderick MP, Academic press. pp. 215-222.

[16] Friedwald, W. T., Levy, R. I., and Fredrickson, D. S., 1972. "Estimation of the concentration of low density lipoprotein cholesterol in plasma, without use of the preparative ultra-centrifuge." Clinical Chemistry, vol. 18, pp. 499-502.

[17] Warnick, G. R., Nguyan, T., and Albers, A. A., 1985. "Comparison of improved precipitation methods for quantification of high density lipoprotein cholesterol." Clinical Chemistry, vol. 31, pp. 217-222.

[18] Sinha, K. A., 1972. "Colorimetric assay of catalase." Annals Clinical Biochemistry, vol. 7, pp. 389-94.

[19] Das, K., Samanta, L., and Chainy, G. B. N., 2000. "A modified spectrophotometric assay of superoxide dismutase using formation by superoxide radicals." Indian Journal of Biochemistry and Biophysics, vol. 37, pp. 201-204.

[20] Moron, M. S., Depierre, J. W., and Mannervik, B., 1979. "Levels of glutathione, glutathione reductase and glutathione S-transferase activities in rat lung and liver." Biochemica et Biophysica ACTA., vol. 582, pp. 6778.

[21] Hardman, J. G. and Limberd, L. E., 2001. Insulin, oral hypoglycemic agents and the pharmacology of the endocrine pancreas. In Goodman and Gilman's: The Pharmacological basis of Therapeutics. USA: Mcgraw-Hill Company Limited. pp. 1383-1399.

[22] Prieto-Hontorian, P. L., Perez-Matute, P., Fernandez-Galilea, M., Barber, A., Martinez, J. A., and MorenoAliaga, M. J., 2009. "Lipoic acid prevents body weight gain induced by a high fat diet in rats: effects on intestinal sugar transport." Journal of Physiology and Biochemistry, vol. 65, pp. 43-50.

[23] Palanivel, R., Thangavel, M., Selvendran, K., and Sakthisekaran, D., 2001. "Insulinomimetric effect of ammonium paratungstate on protein metabolism in streptozotocin induced diabetic rats." Biomedicine, vol. 21, pp. 23-30.

[24] Chalasani, N., Aljadhey, H., Kesterson, J., Murray, M. D., and Hall, S. D., 2004. "Patients with elevated liver enzymes are not act high risk for station hepatotoxicity." Gastroenterology, vol. 126, pp. 1287-1292.

[25] Stanely, P., Prince, M., and Menon, V., 1999. "Hypoglycemic and other related actions of Tinospora cordifolia roots in alloxan induced diabetic rats." Journal of Ethnopharmacology, vol. 70, pp. 9-15.

[26] Hwang, H. J., Kim, S. W., Lim, J. M., Joo, J. H., Kim, H. O., Kim, H. M., and Yun, J. W., 2005. "Hypoglycemic effect of crude epoxy polysaccharides produced by a medicinal mushroom Phellinus baumii in streptozotocin induced diabetic rats." Life Science, vol. 76, pp. 3069-3080.

[27] Reddy, A. C. and Lokesh, B. R., 1992. "Studies on spices principles as antioxidants in the inhibiting of lipid peroxidation of rat liver microsomes." Molecular and Cellular Biochemistry, vol. 111, pp. 117-124.

[28] Dhuley, J. N., Raman, P. H., M., M., and Naik, S. R., 1993. "Inhibition of lipid peroxidation by piperine during experimental inflammation in rats." Indian Journal of Experimental Biology, vol. 31, pp. 443-445.

[29] Selvendiran, K., Senthilnathan, P., Magesh, V., and Sakthisekaran, D., 2004. "Modulatory effect of piperine on mitochondrial antioxidant system in Benzo(a) pyrene-induced experimental lung carcinogenesis." Phytomedicine, vol. 11, pp. 85-89.

[30] Anderson, D., Yu, T. W., Phillips, J. B., and Schmezer, D., 1994. "The effect of various antioxidants and other modifying agents on oxygen radical generated DNA damage in human lymphocytes." Mutation Research, vol. 307, pp. 261-271.

[31] Slaga, T. J., 1995. "Inhibition of the induction of cancer by antioxidants." Advances in Experimental Medicine and Biology, vol. 369, pp. 167-174. 